\title{
Coccolithophores and the biological pump: responses to environmental changes
}

\author{
Björn ROST ${ }^{1}$ and Ulf RIEBESELL ${ }^{2}$ \\ ${ }^{1}$ Pelagic Ecosystems, Alfred Wegener Institute for Polar and Marine Research, Am Han- \\ delshafen 12, D-27570 Bremerhaven, Germany. brost@awi-bremerhaven.de \\ ${ }^{2}$ Marine Biogeochemistry, Institute for Marine Research, University of Kiel, Duestern- \\ brooker Weg 20, 24105 Kiel, Germany. uriebesell@ifm.uni-kiel.de
}

\section{Summary}

Coccolithophores, which are considered to be the most productive calcifying organisms on earth, play an important role in the marine carbon cycle. The formation of calcite skeletons in the surface layer and their subsequent sinking to depth modifies upper-ocean alkalinity and directly affects air/sea $\mathrm{CO}_{2}$ exchange. Recent work indicates that the productivity and distribution of coccolithophores are sensitive to $\mathrm{CO}_{2}$-related changes in environmental conditions, both directly through acidification of surface seawater and indirectly through increasing upper-ocean thermal stratification. To assess possible responses of this group we examine the physiology and ecology of coccolithophores with regard to expected environmental changes. Potential feedbacks to atmospheric $\mathrm{CO}_{2}$ increase, as could arise from changes in photosynthesis and calcification as well as from a shift in the dominance of coccolithophores, may be crucial when trying to forecast future climate change.

\section{Introduction}

The climate of the earth has undergone major changes over geologic time-scales. Climatic conditions and changes therein have immediate repercussions for the global biosphere, influencing the structure and productivity of ecosystems and the proliferation or disappearance of organisms. In turn, biological activity can exercise a direct impact on the climate. By driving many of the global elemental cycles, organisms can both mitigate or amplify climate change and may contribute, as suggested by the Gaia hypothesis (Lovelock 1979), to stabilising the climate. Global changes in environmental conditions, including climate conditions, are presently occurring at an unprecedented rate due to large-scale perturbations induced by human activities. While this is bound to give rise to ecosystem changes 
on the global scale, we are only starting to understand the complex interplay between climate variability and ecosystem structure and functioning. Reliable prediction of the direction and magnitude of ecosystem changes, however, would be a prerequisite for assessing the risks involved in human-induced global change.

Despite a high degree of structural complexity, the energy flow and elemental cycling of many ecosystems are dominated by a comparatively small number of species. A first step in understanding possible consequences of environmental change on ecosystem functioning, therefore, is to determine the relevant responses of these key species. This also holds true for the marine pelagic system, the largest ecosystem on our planet. While the base of its complex food web is formed by more than 5000 species of marine phytoplankton, only a few taxonomic groups of phytoplankton, and within these groups a relatively small number of species, are responsible for most of the system's primary production, the energy transfer to higher trophic levels and the vertical export of biogenic material to the deep ocean. These key species can be further distinguished into so-called 'functional groups', i.e. phytoplankton building siliceous or calcareous shells, such as the diatoms and coccolithophores, respectively, flagellates forming organic plates or mucilaginous colonies, and cyanobacteria fixing atmospheric nitrogen. Each of these functional groups has a distinct effect on elemental fluxes, both between the surface and deep ocean as well as the overlying atmosphere.

With regard to the oceanic carbon cycle, the effect of calcifying plankton, including coccolithophores as the dominant calcifying phytoplankton, differs greatly from that of other primary producers (Fig. 1). The fixation of inorganic carbon via photosynthesis in the sunlit upper mixed layer and the vertical export of part of this organic material causes a draw down of $\mathrm{CO}_{2}$ in the surface ocean. Remineralisation of the particulate organic carbon on its way to depth releases organicallybound $\mathrm{CO}_{2}$, which then accumulates in deeper layers. This process, termed the organic carbon pump, thereby causes a net draw down of $\mathrm{CO}_{2}$ from the atmosphere into the ocean. In contrast, the production and export of calcium carbonate has the opposite effect on air/sea $\mathrm{CO}_{2}$ exchange, causing a net release of $\mathrm{CO}_{2}$ to the atmosphere. Due to its counteracting effect on $\mathrm{CO}_{2}$ flux, this process is often referred to as the carbonate counter pump (while $\mathrm{CO}_{2}$ release through carbon fixation may appear counter-intuitive, the intricacies of the underlying carbonate chemistry will be outlined below). The relative strength of the two biological carbon pumps, represented by the so-called rain ratio (the ratio of particulate inorganic to organic carbon in exported biogenic matter), to a large extent determines the flux of $\mathrm{CO}_{2}$ between the surface ocean and the overlying atmosphere.

Recent work indicates that changes in seawater carbonate chemistry caused by rising atmospheric $\mathrm{CO}_{2}$ (Fig. 2) can decrease biologically-mediated calcification (Gattuso et al. 1998; Wolf-Gladrow et al. 1999; Riebesell et al. 2000a; Zondervan et al. 2001). Changes in seawater $\mathrm{CO}_{2}$ concentration and/or $\mathrm{CO}_{2}$-related changes of the carbonate system are also likely to modify phytoplankton species composition (Tortell et al. 2002), and may even alter the relative abundance of calcifying versus non-calcifying phytoplankton (Rost et al. 2003). Since changes in atmospheric $\mathrm{pCO}_{2}$ give rise to corresponding changes in the carbonate system of surface 


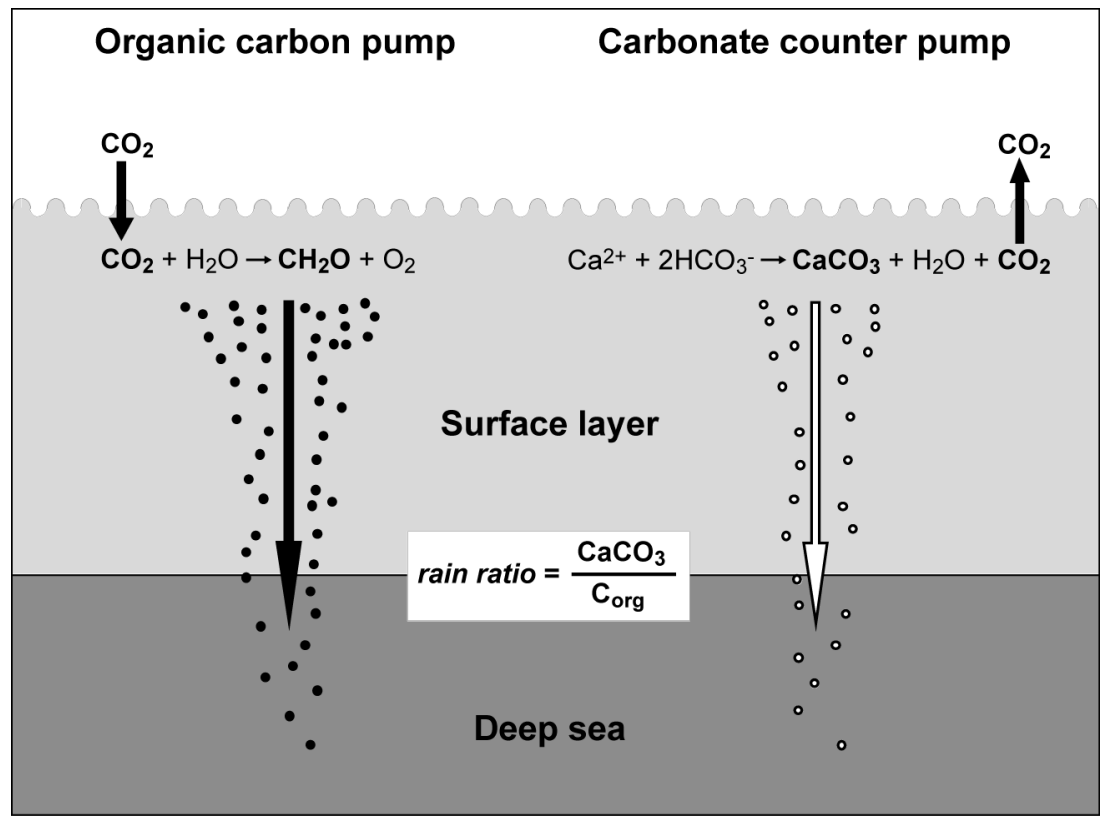

Fig. 1. The biological carbon pumps: Photosynthetic production of organic matter in the surface layer and its subsequent transport to depth, termed organic carbon pump, generates a $\mathrm{CO}_{2}$ sink in the ocean. In contrast, calcium carbonate production and its transport to depth, referred to as the calcium carbonate pump, releases $\mathrm{CO}_{2}$ in the surface layer. The relative strengths of these two processes (rain ratio) largely determine the biologicallymediated ocean atmosphere $\mathrm{CO}_{2}$ exchange.

seawater with a time lag of less than one year (Zeebe and Wolf-Gladrow 2001), biological responses may occur in phase with the present rise in atmospheric $\mathrm{CO}_{2}$. Moreover, expected climate-induced changes in surface-ocean temperature, stratification, and mixing, and the related changes in mixed layer light conditions and nutrient cycling (Fig. 3), are bound to affect the structure and composition of marine pelagic ecosystems. These changes will have profound effects on the biological carbon pumps, both in absolute terms and with respect to their relative strengths.

In view of the rapid changes in environmental conditions presently occurring on a global scale, a major challenge in earth system sciences is to predict biospheric responses to global change. Any attempt to forecast biologically-mediated changes in marine biogeochemical cycling critically depends on our ability to explain the distribution and succession of the dominant phytoplankton groups in relation to biotic and abiotic environmental conditions. At present, we are far from understanding phytoplankton succession and distribution in today's ocean, let alone possible modifications therein in response to environmental change. In this 


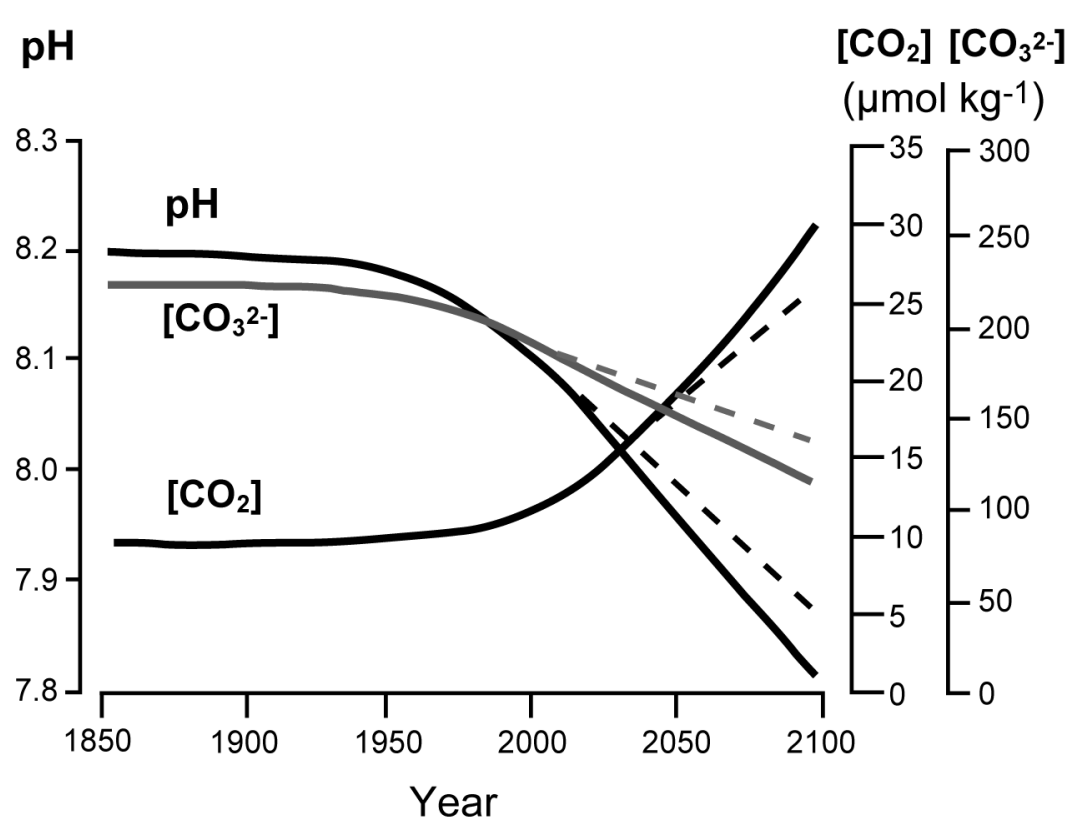

Fig. 2. Seawater $\mathrm{pH}$ and the dissolved carbon dioxide $\left(\mathrm{CO}_{2}\right)$ and carbonate ion $\left(\mathrm{CO}_{3}{ }^{2-}\right)$ concentrations in the surface layer of the ocean assuming a "business as usual" (IS92a) anthropogenic $\mathrm{CO}_{2}$ emission scenario (Houghton et al. 1995). Dashed lines represent the predicted changes in carbonate chemistry if $\mathrm{CO}_{2}$ emissions are reduced according to the Kyoto Protocol (modified after Wolf-Gladrow et al. 1999).

chapter we will outline some of the relevant characteristics of coccolithophores in the framework of environmental change and how these may affect the competitive advantage of this group in the future. While the focus of this paper will be on recent natural and anthropogenic global change, we will also look for possible indications in the geological past and will examine potential consequences for biogeochemical cycling in the ocean in the future.

\section{Biogeochemical role of coccolithophores}

Coccolithophores are a comparatively young group of planktic microalgae, which first appeared in the late Triassic about 200 Mya (million years ago; Bown et al. this volume) and started to produce conspicuous accumulations of calcium carbonate in the rock record since the late Jurassic (ca. 150 Mya) (Morse and Mackenzie 1990). From this point on, coccolithophores have had a major impact on marine biogeochemical cycling with tremendous consequences for earth's climate. Together with planktic foraminifera, which became prominent in the 


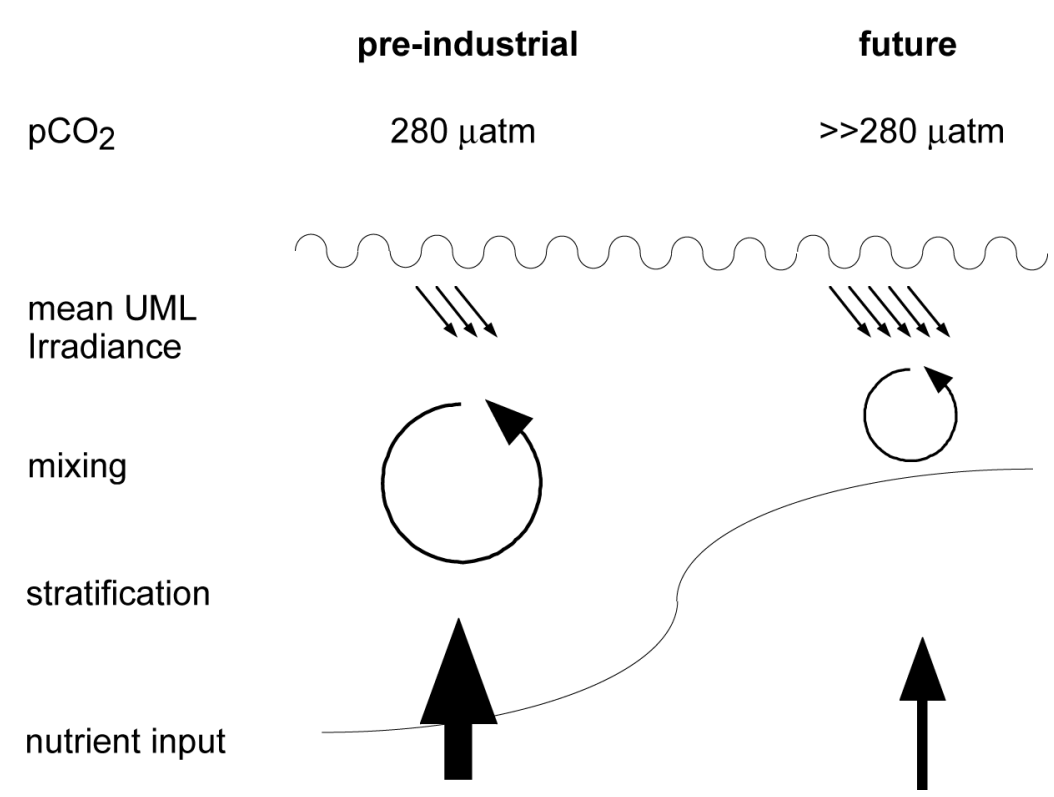

Fig. 3. The progressive increase in atmospheric $\mathrm{CO}_{2}$ affects the marine biota in various ways: directly through changes in surface ocean chemistry (see Fig. 2) and indirectly through rising mean global temperatures causing increased surface ocean stratification. This in turn reduces the nutrient input from deeper layers and increases the light availability due to shoaling of the upper mixed layer (UML).

Middle Cretaceous (ca. 100 Mya), coccolithophores are mainly responsible for creating and maintaining the ocean's vertical gradient in seawater alkalinity. The coupling between calcification and photosynthesis in coccolithophores, and to some extend also in the symbiont-bearing foraminifera, implies that large-scale calcification is concentrated in the photic zone of the ocean. $\mathrm{CaCO}_{3}$ formation not only binds dissolved carbon into particulate carbon and thereby reduces total dissolved inorganic carbon, it also lowers seawater alkalinity and changes the equilibrium between the different forms of dissolved inorganic carbon. The draw down and vertical flux of $\mathrm{CaCO}_{3}$-bound inorganic carbon and alkalinity drives the carbonate counter pump and consequently causes an increase in atmospheric $\mathrm{pCO}_{2}$.

But how can a process transporting inorganic carbon from the surface to the deep ocean be responsible for maintaining high atmospheric $\mathrm{pCO}_{2}$ ? The formation of one unit of calcium carbonate according to

$$
\mathrm{Ca}^{2+}+\mathrm{CO}_{3}{ }^{2-} \rightarrow \mathrm{CaCO}_{3}
$$

lowers the dissolved inorganic carbon $(D I C)$ concentration, with

$$
\mathrm{DIC}=\left[\mathrm{CO}_{2}\right]+\left[\mathrm{HCO}_{3}^{-}\right]+\left[\mathrm{CO}_{3}{ }^{2-}\right]
$$


by one unit. Due to its double negative charge the concentration of carbonate ions carries the factor 2 in the expression of total alkalinity (TAlk), with

$$
\mathrm{TAlk}=\left[\mathrm{HCO}_{3}{ }^{-}\right]+2\left[\mathrm{CO}_{3}{ }^{2-}\right]+\left[\mathrm{B}(\mathrm{OH})_{4}{ }^{-}\right]+\left[\mathrm{OH}^{-}\right]-\left[\mathrm{H}^{+}\right]
$$

Thus, the precipitation of one unit of calcium carbonate lowers seawater alkalinity by two units. How this affects the concentration of dissolved $\mathrm{CO}_{2}$ is best illustrated, following Zondervan et al. (2001), by plotting $\mathrm{CO}_{2}$ concentration as a function of DIC and TAlk (Fig. 4). Starting at typical surface ocean conditions of DIC $=2.0 \mathrm{mmol} \mathrm{kg}^{-1}$ and $\mathrm{TAlk}=2.3 \mathrm{mmol} \mathrm{kg}$ (beginning of diagonal vector on left side), the corresponding $\mathrm{CO}_{2}$ concentration, $\mathrm{CO}_{2}$, is $10.5 \mu \mathrm{mol} \mathrm{kg}{ }^{-1}$ (assuming $\mathrm{T}=15^{\circ} \mathrm{C}, \mathrm{S}=35$ ). Precipitating $50 \mu \mathrm{mol} \mathrm{kg}{ }^{-1}$ of $\mathrm{CaCO}_{3}$ lowers DIC and TAlk by 0.05 and $0.1 \mathrm{mmol} \mathrm{kg}^{-1}$, respectively. With the new DIC and TAlk values of 1.95 mmol kg-1 and $2.2 \mathrm{mmol} \mathrm{kg}^{-1}$ (end of diagonal vector), the corresponding $\mathrm{CO}_{2}$ concentration now is $12.4 \mu \mathrm{mol} \mathrm{kg}$. Assuming that the seawater initially was in equilibrium with the atmosphere with respect to $\mathrm{CO}_{2}$, it is now $\mathrm{CO}_{2}$ oversaturated. To restore equilibrium, 0.63 units of $\mathrm{CO}_{2}$ need to be released for each unit of inorganic carbon precipitated via calcification. In our example, $50 \mu \mathrm{mol}$ $\mathrm{kg}^{-1} \mathrm{CaCO}_{3}$ production would require a degassing of $32 \mu \mathrm{mol} \mathrm{kg}{ }^{-1}$ of $\mathrm{CO}_{2}$ in order to maintain $\mathrm{CO}_{2}$ equilibrium between our parcel of seawater and the overlying atmosphere. Due to the decrease in the buffer capacity with increasing $\mathrm{CO}_{2}$ (decreasing $\mathrm{pH}$ ) of seawater, the ratio of $\mathrm{CO}_{2}$ released per carbonate precipitated increases with rising atmospheric $\mathrm{CO}_{2}$ (Frankignoulle et al. 1994). Under conditions expected for the year 2100 (see Fig. 2), the surface ocean equilibrium $\mathrm{CO}_{2}$ concentration would be ca. $27 \mu \mathrm{mol} \mathrm{kg}$. Under these conditions, precipitation of 50 $\mu \mathrm{mol} \mathrm{kg}{ }^{-1} \mathrm{CaCO}_{3}$ would release ca. $40 \mu \mathrm{mol} \mathrm{kg}{ }^{-1}$ of $\mathrm{CO}_{2}$, corresponding to 0.79 units of $\mathrm{CO}_{2}$ for each unit of $\mathrm{CaCO}_{3}$ (right vectors). If global calcification were to remain constant over this time, increased calcification-induced $\mathrm{CO}_{2}$ release results in a positive feedback to rising atmospheric $\mathrm{CO}_{2}$ (Zondervan et al. 2001).

Aside from their predominant role in global ocean calcification, coccolithophores are also important primary producers. Their geographical distribution ranges from oligotrophic subtropical gyres to temperate and high latitude eutrophic regimes. Representatives of this group equally strive in low chlorophyll recycling systems as well as in high biomass new production systems. Of the ca. 200 species of coccolithophores, however, only very few species form intense blooms over large areas of the ocean (Tyrrell and Merico this volume). Among these, Emiliania huxleyi and Gephyrocapsa oceanica are by far the most prominent bloom-formers. As calcifying primary producers, coccolithophores contribute to both the organic carbon pump and the carbonate counter pump. The draw down of $\mathrm{CO}_{2}$ due to organic carbon production is thereby partly compensated by the release of $\mathrm{CO}_{2}$ via calcification. Primary production by coccolithophores is therefore a smaller sink for $\mathrm{CO}_{2}$ when compared to a non-calcifying production system, such as a diatom bloom (Robertson et al. 1994). Due to calcite overproduction, a phenomenon typical for Emiliania huxleyi when growing into nutrient limitation, blooms of this species can even turn into a net source for $\mathrm{CO}_{2}$ to the atmosphere (Purdie and Finch 1994). Obviously, the ratio of coccolithophore calcification to organic matter production, but even more so the ratio of calcareous to non- 


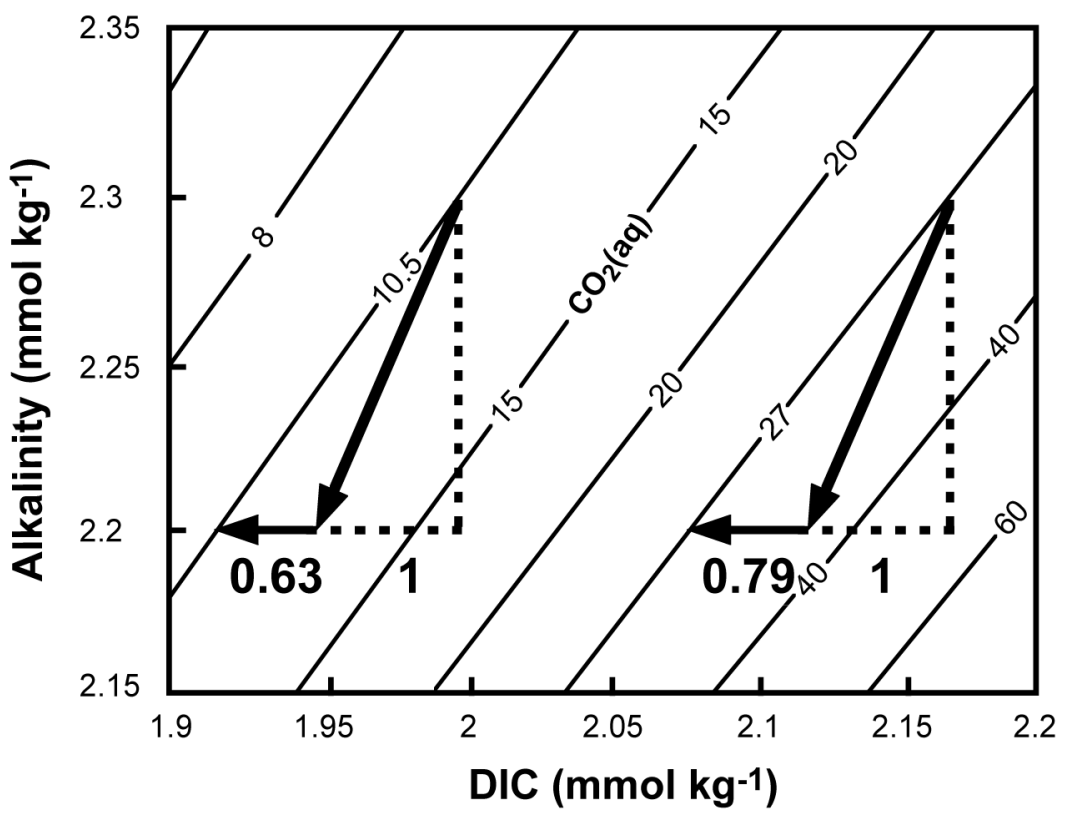

Fig. 4. Changes in the concentrations of DIC, total alkalinity, and $\mathrm{CO}_{2}$ as a result of calcification at pre-industrial times (left vectors) and in year 2100 (right vectors). Numbers at the vectors are relative values. The difference in the effect of calcification on seawater carbonate chemistry in the two scenarios results from a $\mathrm{CO}_{2}$-related change in the seawater buffer capacity (see text for details, modified after Zondervan et al. 2001).

calcareous primary production, strongly determine the relative strengths of the two biological carbon pumps. $\mathrm{CaCO}_{3}$ may also act as a "ballast" mineral that increases the transfer efficiency of POC from the surface to the deep sea (Armstrong et al. 2002). The presence of coccoliths could thus enhance the sedimentation of POC such as in faecal pellets (Buitenhuis et al. 1996). According to this "ballast" hypothesis variations in the rain ratio would have been generally smaller than previously assumed (Armstrong et al. 2002; Klaas and Archer 2002).

On geological time-scales variation in coccolith abundance in the sedimentary record is often correlated with glacial-interglacial transitions, indicating a predominance of coccolithophores during interglacial periods (McIntyre et al. 1972; Henrich 1989). The presumably lower contribution of coccolithophores relative to non-calcifying phytoplankton may have contributed to the lower atmospheric $\mathrm{CO}_{2}$ levels in glacial times (Archer and Maier-Reimer 1994; Harrison 2000; Ridgwell et al. 2002). A large-scale effect of present climate forcing on the relative contribution of calcareous to primary production is indicated by a basin-wide shift in the composition of sedimenting particles in the North Atlantic (Antia et al. 2001). The 
observed steady decrease in the opal:carbonate ratio since the early eighties may reflect an increase in the abundance and productivity of coccolithophores relative to diatoms. Changes in environmental conditions related to climate forcing are likely to affect phytoplankton functional groups differently (Boyd and Doney 2002). Forecasting the response of marine ecosystems to global change therefore requires an understanding of the factors that determine the distribution and productivity of key phytoplankton groups. A first step to assessing the sensitivity of coccolithophores to environmental change will be to examine the physiology and ecology of this group in relation to other dominant phytoplankton taxa.

\section{Coccolithophore ecophysiology}

Most of our information about the physiology and ecology of coccolithophores originates form the extensive work on Emiliania huxleyi, a species that is somewhat unusual for the group of coccolithophores. It has evolved only 270.000 years ago from the older genus Gephyrocapsa (Thierstein et al. 1977), became dominant 70.000 years ago and is now the most abundant coccolithophore in the ocean. Only few coccolithophores form blooms like E. huxleyi, thus E. huxleyi is more rselected (i.e. pioneer) than most other coccolithophores. Other specialities are the phenomenon of coccolith-overproduction and the lack of light-inhibition in this species. For an extensive review on E. huxleyi we refer to Paasche et al. (2002). In view of the current increase in atmospheric $\mathrm{pCO}_{2}$, coccolithophores could be affected in various ways: directly through changes in surface ocean carbonate chemistry (Fig. 2), and indirectly through rising mean global temperatures causing increased surface ocean stratification with respective changes in the light regime and nutrient supply (Fig. 3). In the following sections on photosynthesis and calcification we will therefore focus on the effect of light, inorganic carbon and other nutrients. Furthermore, possible interactions between calcification and photosynthesis will be discussed.

\section{Photosynthesis and growth}

Photosynthesis involves a series of reactions that start with capturing light energy, transferring it into the energy-conserving compounds NADPH and ATP, and using these compounds to fix $\mathrm{CO}_{2}$ in the Calvin cycle. Actively growing algae allocate about $50 \%$ of recent photosynthate to protein synthesis, resulting in a competition for NADPH and ATP between $\mathrm{CO}_{2}$ fixation, transport processes, nitrate reduction and protein formation (Geider and MacIntyre 2001). Thus photosynthesis and downstream processes leading to cellular growth are primarily lightdependent processes. Photosynthesis-irradiance response curves are commonly used to assess the photosynthetic performance. Parameters derived from these curves such as the light-saturated photosynthetic rate $\left(\mathrm{P}_{\mathrm{m}}\right)$, light-limited initial slope $(\alpha)$, maximum quantum yield $\left(\Phi_{\mathrm{m}}\right)$ as well as Chl $a$ :C ratios are similar for 
E. huxleyi to those of other phytoplankton species (Nielsen 1997). Yet, with lightsaturation irradiances $\left(E_{k}\right)$ between 70 and $300 \mu \mathrm{mol}$ photons $\mathrm{m}^{-2} \mathrm{~s}^{-1}$ (e.g. Paasche 1967; Van Bleijswijk et al. 1994; Nielsen 1997), E. huxleyi reaches saturation levels at irradiances generally higher than those found for diatoms or dinoflagellates (Richardson et al. 1983). Moreover, elevated irradiances have no or little inhibitory effect on photosynthesis of E. huxleyi, which has been verified for irradiances up to $1700 \mu \mathrm{mol}$ photons $\mathrm{m}^{-2} \mathrm{~s}^{-1}$ (e.g. Nielsen 1995; Nanninga and Tyrrell 1996). The tolerance of E. huxleyi to high light intensities is also reflected in its predominance during times when surface waters are highly stratified in the summer (Nanninga and Tyrrell 1996; Tyrrell and Taylor 1996).

In the dark reaction of photosynthesis $\mathrm{CO}_{2}$ is fixed by the carboxylating enzyme, ribulose-1,5-bisphosphate carboxylase/oxygenase (RubisCO). Due to the poor substrate affinity of RubisCO for $\mathrm{CO}_{2}\left(\mathrm{~K}_{\mathrm{M}} 20-70 \mu \mathrm{mol} \mathrm{L}{ }^{-1}\right.$, Badger et al. $1998)$ and the low $\mathrm{CO}_{2}$ concentrations present in seawater $\left(5-25 \mu \mathrm{mol} \mathrm{L} \mathrm{L}^{-1}\right)$ photosynthesis of phytoplankton potentially suffers from $\mathrm{CO}_{2}$ limitation. To overcome the imperfection of their main carboxylating enzyme, most microalgae have developed mechanisms to enhance the $\mathrm{CO}_{2}$ concentration at the site of carboxylation. These $\mathrm{CO}_{2}$ concentrating mechanisms (CCMs) comprise active uptake of $\mathrm{CO}_{2}$ and/or $\mathrm{HCO}_{3}{ }^{-}$into the algal cell and/or the chloroplast. Also involved in most $\mathrm{CCM}$ is the enzyme carbonic anhydrase (CA), which accelerates the otherwise slow rate of conversion between $\mathrm{HCO}_{3}^{-}$and $\mathrm{CO}_{2}$. Owing to the operation of CCMs, most marine phytoplankton have high affinities for inorganic carbon and reach photosynthetic carbon saturation under ambient $\mathrm{CO}_{2}$ levels (Raven and Johnston 1991).

Unlike other dominant phytoplankton groups Emiliania huxleyi has comparatively low affinities for inorganic carbon and photosynthesis appears to be carbonlimited in today's ocean (e.g. Paasche 1964; Sikes and Wheeler 1982; Nielsen 1995). This has led to the speculation that this species may rely entirely on diffusive $\mathrm{CO}_{2}$ supply for photosynthesis (Raven and Johnston 1991). Recent studies, however, provide clear evidence for active carbon uptake in E. huxleyi (e.g. Nimer and Merret 1996; Rost et al. 2002, 2003). The efficiency of the CCM employed by E. huxleyi appears to be low when compared to other phytoplankton taxa (e.g. Burkhardt et al. 2001; Rost et al. 2003; Fig. 5). In view of close coupling between photosynthesis and calcification it has been hypothesized that E. huxleyi is able to use $\mathrm{HCO}_{3}{ }^{-}$for photosynthesis through the process of calcification (Sikes et al. 1980; Nimer and Merret 1993), potentially representing a cost-effective alternative to the classical $\mathrm{CO}_{2}$ concentrating mechanism (Anning et al. 1996). The potential role of calcification for photosynthetic carbon acquisition will be dealt with in the section on calcification below.

In contrast to photosynthetic carbon fixation, cell division rate of E. huxleyi is not limited by DIC under natural conditions, thus it does not increase under elevated $\mathrm{CO}_{2}$ or DIC concentrations (e.g. Paasche et al. 1996; Buitenhuis et al. 1999; Clark and Flynn 2000; Riebesell et al. 2000b). The "mismatch" between cell division and carbon fixation can cause large variations of carbon cell quota, with low values under sub-saturating irradiances and DIC concentrations, and high values at 


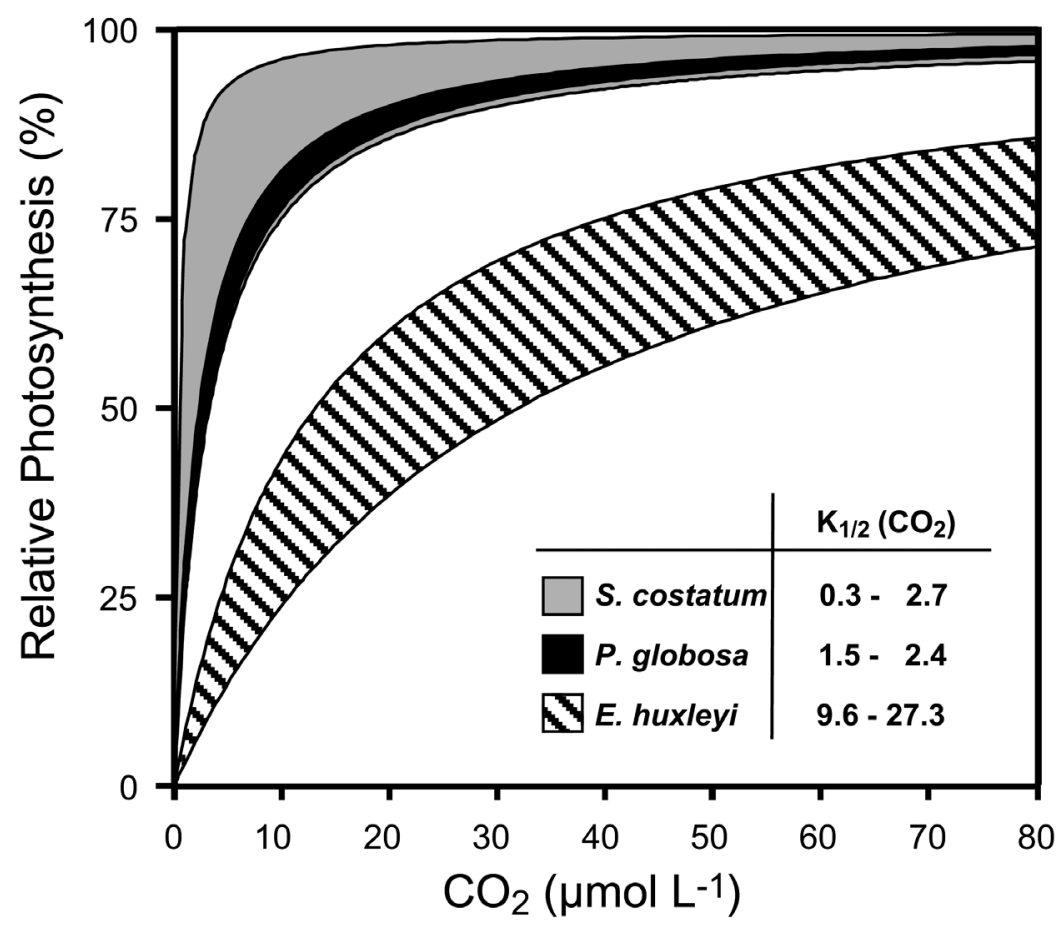

Fig. 5. Photosynthesis of phytoplankton species differs with respect to $\mathrm{CO}_{2}$ sensitivity: While most species (here Skeletonema costatum and Phaeocystis globosa) are at or close to $\mathrm{CO}_{2}$ saturation at present day $\mathrm{CO}_{2}$ levels $\left(8-20 \mu \mathrm{mol} \mathrm{L} \mathrm{L}^{-1}\right)$, coccolithophores such as $E$. huxleyi have comparatively low affinities for inorganic carbon and appear to be carbonlimited in today's ocean. This raises the possibility that coccolithophores may benefit directly from the present increase in atmospheric $\mathrm{CO}_{2}$. The range in half-saturation concentrations $\left(\mathrm{K}_{1 / 2}\right.$; in $\left.\mu \mathrm{mol} \mathrm{L}^{-1}\right)$ for photosynthesis shown here reflects the degree of regulation as a function of $\mathrm{pCO}_{2}$ during growth (according to Rost et al. 2003). Highest apparent affinities for $\mathrm{CO}_{2}$ were generally observed in cells which were grown under low $\mathrm{pCO}_{2}$.

saturating irradiances and DIC concentrations (e.g. Van Bleijswijk et al. 1994; Paasche 1999; Zondervan et al. 2002). The variability in carbon quota is even higher when cell division of E. huxleyi is limited by phosphorus or nitrogen (Paasche 1998; Riegman et al. 2000). The observed high flexibility in its carbon quota may be of ecological relevance, providing a mechanism to maintain high growth rates under limiting conditions. This could reduce constrictions otherwise imposed by the low affinity carbon acquisition. 
In addition to light and carbon, other resources such as phosphorus and nitrogen as well as trace elements are required for the functioning of the photosynthetic apparatus and effective growth. E. huxleyi has extremely high affinity phosphate uptake systems with half-saturation constants as low as $1 \mathrm{nM}$ (Riegman et al. 1992, 2000). A constitutive and an inducible alkaline phosphatase enables the cells to also use organic phosphate esters at nanomolar levels. Despite the ability of E. huxleyi to accumulate surplus phosphate to some degree, luxury consumption for phosphate is rather low relative to other species. With regard to nitrate utilisation, E. huxleyi was not found to be an exceptional competitor under Nlimitation (Riegman et al. 1992, 2000). Maximum uptake rates are fairly low and the half-saturation constant of $0.2 \mu \mathrm{M}$ is similar or higher than those of other algae (Page et al. 1999; Riegman et al. 2000). Some strains of E. huxleyi can use other $\mathrm{N}$-compounds such as amino acids (Ietswaart et al. 1994), low molecular weight amides, urea, and purines (Palenik and Henson 1997). As in the case of phosphate, luxury consumption for nitrate is low in E. huxleyi compared to other phytoplankton taxa, such as diatoms (Grime 1979; Raven 1997). Iron and zinc requirements of E. huxleyi are lower than of coastal diatoms but comparable with those of other oceanic phytoplankton species (Brand 1991; Sunda and Huntsmann 1995; Muggli and Harrison 1996; Morel et al. 1994). Owing to the exceptionally high affinity for phosphate as well as its ability to use organic phosphate esters, however, E. huxleyi can outcompete other phytoplankton species under elevated N:P ratios (Riegman et al. 1992, 2000).

\section{Calcification and its relation to photosynthesis}

Despite intensive research on coccolithophores the function of calcification is still not completely understood (Young 1994; Brownlee et al. 1994; Paasche 2002; Brownlee and Taylor this volume). It has been hypothesized that the cell-covering layer of coccoliths, the coccosphere, serves to protect against grazing and/or virus attack and that coccoliths could bundle and modify the light intercepted by the algal cell (Young 1994). While these hypotheses amongst various others remain speculative, there is some support for the "trash-can function" of calcification, whereby $\mathrm{CaCO}_{3}$ precipitation serves as a mechanism to facilitate the use of bicarbonate in photosynthesis (see below). The ratio of calcification to photosynthesis in coccolithophores, in the literature often referred to as the $\mathrm{C} / \mathrm{P}$ or PIC/POC ratio, has recently received much attention as it provides information on the carbon metabolism of coccolithophores and bears implications for the rain ratio. In the following the light-, carbon- and nutrient-dependence of calcification will be discussed in comparison to photosynthesis, with emphasis on respective changes in the PIC/POC ratio.

Calcification of coccolithophores is predominantly a light-dependent process. This has been shown in numerous incubation experiments for E. huxleyi (e.g. Paasche 1962, 1964, 1965, 1966; Sikes et al. 1980; Linschooten et al. 1991) as well as Coccolithus pelagicus (Paasche 1969) and has been verified also under natural conditions in mesocosm and shipboard experiments (e.g. Van der Wal et 
al. 1995; Balch et al. 1992; Holligan et al. 1993). Due to the different lightdependence of calcification compared to photosynthesis, the PIC/POC ratio in $E$. huxleyi generally decreases towards low growth irradiances (e.g. Van Bleijswijk et al. 1994; Balch et al. 1996; Paasche 1999; Zondervan et al. 2002). Balch et al. (1996) suggested that this light-dependence in PIC/POC offers an ecological adaptation strategy. Ceasing calcification under extreme light-limitation, as it occurs at the base of the photic zone, lowers cell density and thus may reduce the loss of cells through sinking below the photic zone. Since calcification continues when growth is limited by nutrient deficiency it could also provide a means of dissipating absorbed light energy to avoid photo-damage under nutrient limitation (Paasche 2002).

Both calcification and photosynthesis draw carbon from the large pool of dissolved inorganic carbon in seawater. While for photosynthesis, both $\mathrm{CO}_{2}$ and $\mathrm{HCO}_{3}{ }^{-}$are used in variable proportion, for calcification, $\mathrm{HCO}_{3}{ }^{-}$is thought to be the main or only carbon source (Paasche 1964; Sikes et al. 1980). A predominantly $\mathrm{HCO}_{3}{ }^{-}$based calcification is indicated by the $\delta^{13} \mathrm{C}$ composition of the coccoliths, which is close to the $\delta^{13} \mathrm{C}_{\text {of }} \mathrm{HCO}_{3}{ }^{-}$(Sikes and Wilbur 1982; Rost et al. 2002). Increasing DIC was found to increase the rate of calcification in E. huxleyi (Paasche 1964; Buitenhuis et al. 1999; Berry et al. 2002). While elevated $\mathrm{CO}_{2}$ concentrations under constant DIC have been shown to reduce calcification in lightsaturated cultures of E. huxleyi and G. oceanica (Riebesell et al. 2000a), this trend in calcification was not observed under light-limitation (Zondervan et al. 2002). Under $\mathrm{N}$ - and P-limitation the responses in calcification to different $\mathrm{CO}_{2}$ or DIC concentrations seems more pronounced than in nutrient replete cultures. Berry et al. (2002) investigated a low calcifying strain of E. huxleyi and observed a stimulation in the rate of calcification upon DIC enrichment (constant $\mathrm{pH}$ ) as well as under decreasing $\mathrm{CO}_{2}$ concentrations (increasing $\mathrm{pH}$ ). Due to different responses of calcification and photosynthesis to changes in carbonate chemistry, the PIC/POC ratio in E. huxleyi generally increases with decreasing $\mathrm{CO}_{2}$ or increasing DIC concentrations (Paasche 1964; Riebesell et al. 2000a; Berry et al. 2002; Zondervan et al. 2002; Fig. 6). This trend persists over a range of irradiances and only weakens under severe light limitation. Most of this change is caused by the response in photosynthesis, which is generally more sensitive to changes in $\mathrm{CO}_{2}$ and DIC concentration than calcification. Phosphorus and nitrogen limitation was stated to stimulate calcification (e.g. Riegman et al. 2000; Berry et al. 2002), which is often deduced from the observed increase in the PIC/POC ratio upon nutrient limitation. While under nutrient replete conditions PIC/POC ratios are generally below unity, under $\mathrm{P}$ - and N-limitation values up to 2.3 have been observed (cf. Paasche 2002). This led to the suggestion that calcification plays a role in nutrient acquisition such as phosphorus metabolism. In fact, E. huxleyi has the highest affinity for phosphate of all investigated phytoplankton species (Riegman et al. 2000). Moreover, phosphorus deficiency induced recalcification of a noncalcifying strain of E. huxleyi (Paasche 1998). High PIC/POC ratios under low nutrient conditions may in some cases, however, simply reflect the lower nutrient dependency of calcification compared to photosynthesis. Since coccolith forma- 


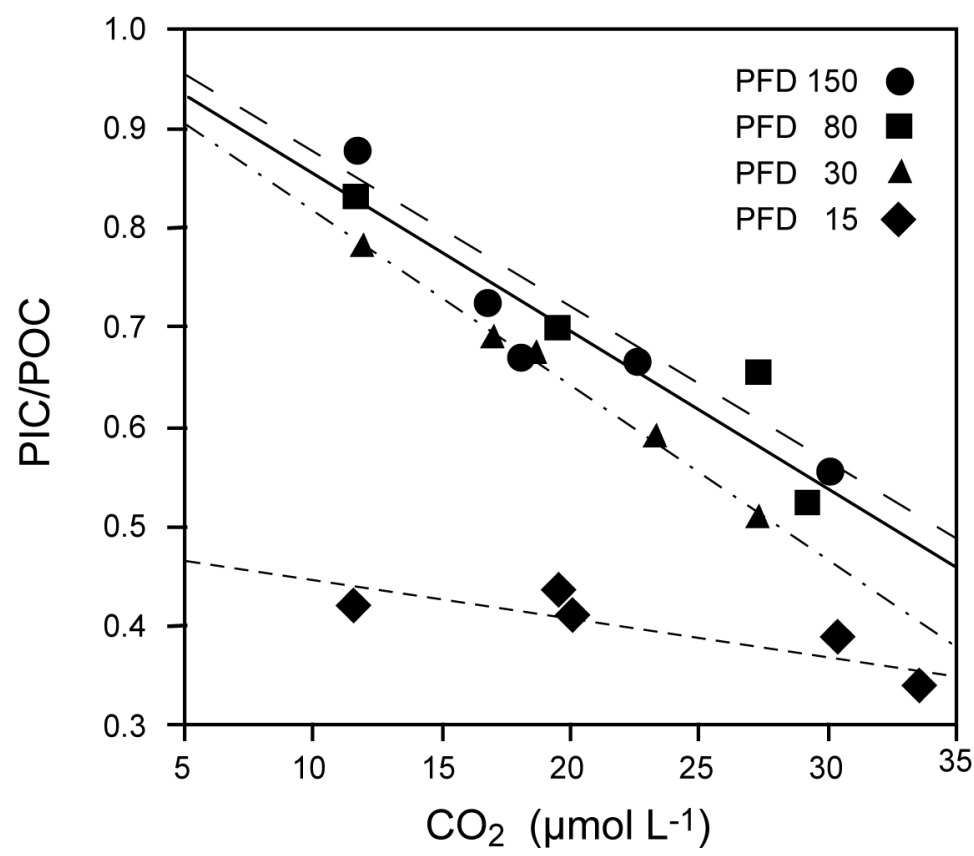

Fig. 6. Rising $\mathrm{CO}_{2}$ decreases the ratio of calcification to organic carbon production (PIC/POC) in E. huxleyi. The decrease in PIC/POC is caused by enhanced photosynthetic carbon fixation and reduced or constant calcification. This trend is consistent over a range of photon flux densities (PFDs; in $\mu$ mol photons $\mathrm{m}^{-2} \mathrm{~s}^{-1}$ ), yet declines under severe lightlimitation (modified after Zondervan et al. 2002).

tion is predominantly a light-dependent process any kind of nutrient limitation affecting the rate of photosynthesis is bound to increase the PIC/POC ratio. This effect was also observed for growth under zinc-limitation (K. Schulz, pers. com.).

To what extent the two cellular processes calcification and photosynthesis are directly coupled is still an open question. While photosynthesis obviously drives calcification by providing the energy required to transport inorganic carbon and calcium ions and to accumulate them inside the coccolith producing vesicles, the question whether calcification is also beneficial for photosynthesis is still unresolved (Brownlee and Taylor this volume). Provided that $\mathrm{HCO}_{3}{ }^{-}$is the carbon source for calcification, one possible benefit for photosynthesis could be the release of $\mathrm{CO}_{2}$ or protons in the course of calcification according to the following reactions:

$$
\begin{gathered}
\mathrm{Ca}^{2+}+2 \mathrm{HCO}_{3}^{-} \rightarrow \mathrm{CaCO}_{3}+\mathrm{CO}_{2}+\mathrm{H}_{2} \mathrm{O} \\
\mathrm{Ca}^{2+}+\mathrm{HCO}_{3}{ }^{-} \rightarrow \mathrm{CaCO}_{3}+\mathrm{H}^{+}
\end{gathered}
$$


Either $\mathrm{CO}_{2}$ could be used directly in photosynthesis or protons could be used in the conversion of $\mathrm{HCO}_{3}^{-}$to $\mathrm{CO}_{2}$. In either case this would provide the calcifying cell with a mechanism to access $\mathrm{HCO}_{3}^{-}$, which represents the largest pool of inorganic carbon in seawater.

A functional coupling between calcification and photosynthesis has first been proposed by Sikes et al. (1980) and has since been favoured by various authors (e.g. Nimer and Merret 1993; Brownlee et al. 1994; Anning et al. 1996; Buitenhuis et al. 1999). While compelling evidence for or against such a mechanism is still lacking, it appears that calcification in coccolithophores is neither a prerequisite for efficient photosynthesis nor is it particularly effective in mitigating $\mathrm{CO}_{2}$ limitation. This is indicated, for example, by the fact that photosynthesis continues unaltered when calcification ceases, such as when cells are grown in calcium-free medium (Paasche 1964). Likewise, non-calcifying cells can photosynthesise as efficiently as, or even more efficiently than, calcifying ones (Fig. 7). Moreover, mass spectrometric measurements indicate that non-calcifying cells of E. huxleyi are capable of direct uptake of $\mathrm{HCO}_{3}{ }^{-}$, which implies that $\mathrm{HCO}_{3}{ }^{-}$utilisation is not tied to calcification. That calcification also appears unsuited to prevent $\mathrm{CO}_{2}$ limitation of coccolithophores is indicated by observations that the rate of photosynthesis decreases with decreasing $\mathrm{CO}_{2}$ concentration despite a concomitant increase in calcification rate (Riebesell et al. 2000a; Berry et al. 2002; Zondervan et al. 2002). In essence, if supply of $\mathrm{CO}_{2}$ for photosynthesis is indeed a primary role of calcification, this mechanism is rather inefficient when compared to $\mathrm{CO}_{2}$ concentrating mechanisms of non-calcifying phytoplankton such as diatoms and Phaeocystis (Burkhardt et al. 2001; Rost et al. 2003).

Despite a wealth of information on the effect of environmental conditions on coccolith production, the mechanism of calcification by coccolithophores is not completely understood (Brownlee and Taylor this volume). Unlike other calcifying organisms, where calcification occurs in the extracellular space, calcite precipitation in coccolithophores takes place in intracellular vesicles and hence is under complete control of the cell. It therefore comes somewhat as a surprise that calcification of coccolithophores shows a similar dependency on seawater carbonate chemistry as in foraminifera and corals (Gattuso et al. 1998; Wolf-Gladrow et al. 1999; Riebesell et al. 2000a; Zondervan et al. 2001). It is still uncertain which is the predominant carbon species used for calcification and which parameters, seawater $\mathrm{pH}, \mathrm{DIC}, \mathrm{CO}_{2}, \mathrm{HCO}_{3}{ }^{-}$or $\mathrm{CO}_{3}{ }^{2-}$ concentration ultimately has the strongest effect on biogenic calcification. For practical purposes a reasonable representation of the effect of carbonate chemistry on biologically-mediated $\mathrm{CaCO}_{3}$ precipitation can be based on the carbonate saturation state of seawater $(\Omega)$ which is expressed as:

$$
\Omega=\frac{\left[\mathrm{Ca}^{2+}\right]_{s w} \times\left[\mathrm{CO}_{3}^{2-}\right]_{s w}}{K_{s p}^{*}}
$$

where $\mathrm{Ca}^{2+}$ sw and $\mathrm{CO}_{3}{ }^{2-}{ }_{\text {sw }}$ are the calcium and carbonate ion concentrations in seawater and $\mathrm{K}_{\mathrm{sp}}^{*}$ is the stoichiometric solubility product, defined as $\mathrm{K}_{\mathrm{sp}}^{*}=\mathrm{Ca}^{2+}{ }_{\text {sat }} \times$ 
$\mathrm{CO}_{3}{ }^{2-}$ sat. Here $\mathrm{Ca}^{2+}$ sat and $\mathrm{CO}_{3}{ }^{2-}$ sat refer to the equilibrium ion concentrations in a seawater solution saturated with $\mathrm{CaCO}_{3}$.

That the carbonate saturation state may be the relevant parameter with regard to possible dependencies of biogenic calcification on seawater chemistry becomes evident when taking a look at the geological past. Recent evidence from fluid inclusions suggests, however, that calcium concentrations in the Cretaceous were more than twice as high as in the modern ocean (Horita et al. 2002). $\mathrm{As}^{\mathrm{CaCO}_{3}}$ compensation tends to restore the saturation state of the ocean towards $\mathrm{CaCO}_{3}$ saturation, higher calcium concentrations would correspond to lower carbonate ion
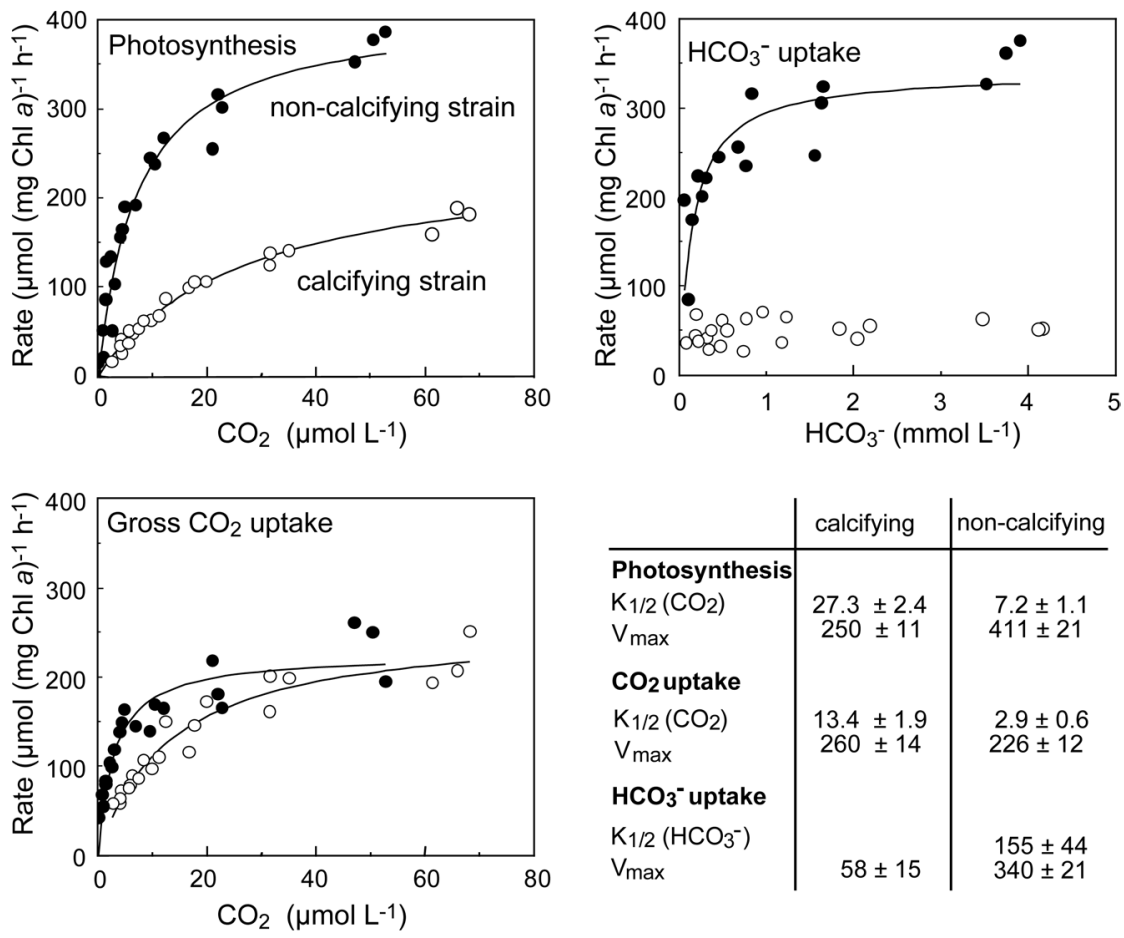

\begin{tabular}{l|r|r} 
& calcifying & non-calcifying \\
\hline Photosynthesis & & \\
$\mathrm{K}_{1 / 2}\left(\mathrm{CO}_{2}\right)$ & $27.3 \pm 2.4$ & $7.2 \pm 1.1$ \\
$\mathrm{~V}_{\max }$ & $250 \pm 11$ & $411 \pm 21$ \\
$\mathrm{CO}_{2}$ uptake & & \\
$\mathrm{K}_{1 / 2}\left(\mathrm{CO}_{2}\right)$ & $13.4 \pm 1.9$ & $2.9 \pm 0.6$ \\
$\mathrm{~V}_{\max }$ & $260 \pm 14$ & $226 \pm 12$ \\
$\mathrm{HCO}_{3}^{-}$uptake $^{-}$ & & \\
$\mathrm{K}_{1 / 2}\left(\mathrm{HCO}_{3}{ }^{-}\right)$ & & \\
$\mathrm{V}_{\max }$ & $58 \pm 15$ & $340 \pm 21$ \\
& &
\end{tabular}

Fig. 7. Comparison of net photosynthesis, gross $\mathrm{CO}_{2}$ uptake, and $\mathrm{HCO}_{3}^{-}$uptake between a calcifying strain (PML B92/11) and a non-calcifying strain of E. huxleyi (obtained from Dr. Elzenga, University of Groningen). Half saturation concentrations $\left(\mathrm{K}_{1 / 2}\right)$ and maximum

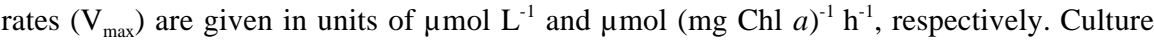
conditions and measurements as in Rost et al. (2003), cells were acclimated to $360 \mathrm{ppmv}$ $\mathrm{CO}_{2}\left(\sim 14 \mu \mathrm{mol} \mathrm{L}^{-1}\right)$. Mass spectrometric procedures according to Badger et al. (1994) allow to estimate both $\mathrm{CO}_{2}$ and $\mathrm{HCO}_{3}{ }^{-}$uptake by utilizing the chemical disequilibrium which exists between $\mathrm{CO}_{2}$ and $\mathrm{HCO}_{3}^{-}$during photosynthesis. The non-calcifying strain photosynthesises more efficiently than the calcifying one. Moreover, the non-calcifying cells of $E$. huxleyi are capable of direct uptake of $\mathrm{HCO}_{3}^{-}$, which implies that $\mathrm{HCO}_{3}^{-}$utilisation is not tied to calcification. 
concentrations. In spite of lower expected $\mathrm{CO}_{3}{ }^{2-}$ concentration, massive accumulation of biogenic carbonates occurred in the Cretaceous, suggesting that the carbonate saturation state may exert a stronger control on biogenic calcification than any of the other possible candidates, e.g. $\mathrm{pH}, \mathrm{CO}_{2}$, or $\mathrm{CO}_{3}{ }^{2-}$ concentrations.

As an interesting side-line we note that the evolutionary development and proliferation of the two dominant pelagic calcifiers, coccolithophores and foraminifera, coincides with a period of high seawater calcium concentrations. All living organisms use calcium in signal transduction and hence need to keep intracellular calcium at extremely low levels. If higher than present seawater calcium concentrations were indeed detrimental to marine organisms, calcification may provide an efficient way of maintaining the balance between high external and low intracellular calcium concentrations. In such a scenario, the accumulation of massive coccolith chalks in the late Cretaceous, which may have contributed to the concomitant rapid decline in seawater calcium concentrations (Volk 1989), would have improved living conditions in the marine environment. Whether or not calcite precipitation has provided calcifying organisms with a competitive advantage over non-calcifiers under elevated calcium concentrations remains to be tested.

\section{Ecology}

The ecological success of a phytoplankton species is ultimately determined by its ability to optimise the balance between growth and loss processes. While the former is largely controlled by the availability and optimal utilisation of essential resources, such as light and nutrients, the latter includes factors such as cell sinking, cell mortality due to grazing, viral and parasite infection, as well as autolysis. Any investment successfully reducing mortality therefore weighs equally strong as cellular measures capable of increasing cell growth by the same magnitude. Coccolithophores apparently cover the entire range of the spectrum from growthmaximising to loss-minimising strategies. The ecological niche occupied by coccolithophores extends from subtropical, oligotrophic recycling systems to temperate and sub-polar, semi-eutrophic new production systems. Understanding the distribution and succession of coccolithophores in today's ocean requires detailed information on the physiological and ecological characteristics of the individual species. In this sense, Emiliania huxleyi is probably one of the best-studied phytoplankton species that is of relevance in the ocean. By comparing the physiological characteristics of coccolithophores with the environmental conditions under which they flourish, we will look for patterns explaining the seasonal and spatial distribution of $E$. huxleyi in relation to other dominant phytoplankton groups.

Due to vertical mixing of the upper surface layer, phytoplankton experiences high variability in light conditions. These stochastic changes are superimposed on diurnal and seasonal variation in solar irradiance. Seasonal changes in thermal stratification, which influence the depth of vertical mixing, further modify the light conditions encountered by a phytoplankton cell. Depending on their photosynthetic characteristics, phytoplankton differ in their ability to cope with variable 
irradiance. While diatoms usually dominate in turbulent, low-stratified waters and are commonly the first to bloom when the water column begins to stabilize early in the seasonal cycle, E. huxleyi blooms predominantly occur in well-stratified waters in late spring/early summer, with mixed layer depths usually between 10 and $20 \mathrm{~m}$, but always $\leq 30 \mathrm{~m}$ (Balch et al. 1991; Robertson et al. 1994; Tyrrell and Taylor 1996; Ziveri et al. 2000; Tyrrell and Merico this volume). This may indicate that the photosynthetic apparatus of diatoms is better adapted to operate efficiently under variable and, on average, lower light intensities. A comparison of photosynthetic parameters between the two groups, however, does not reveal any obvious characteristics which would imply a competitive advantage of diatoms over E. huxleyi under these conditions with the exception that E. huxleyi has a slightly higher light saturation irradiance for growth compared to diatoms (see above).

A distinct difference between diatoms and E. huxleyi is observed with respect to light inhibition. E. huxleyi has an unusual tolerance for high light intensity (Nielsen 1995; Nanninga and Tyrrell 1996). The lack of photoinhibition is surprising considering that photosynthetic carbon fixation of E. huxleyi is carbonlimited under ambient $\mathrm{CO}_{2}$ concentrations (e.g. Paasche 1964; Nielsen 1995; Rost et al. 2003). The latter would imply that when suddenly exposed to high light conditions, E. huxleyi could potentially suffer from a shortage of electron acceptors. Elevated irradiances were found to stimulate calcification of E. huxleyi, especially under P-limitation (Paasche and Brubak 1994; Paasche 1998). It was therefore suggested that calcification provides a means to dissipate excess energy and thereby reduce the risk of photo-damage under high irradiances (Paasche 2002).

Surface layer stratification strongly reduces the input of nutrients from deeper layers. Highly stratified waters therefore are typically characterised by limited nutrient availability. E. huxleyi blooms generally coincide with relatively low levels of nutrients, in particular with respect to phosphate. Whereas nitrate concentrations during blooms of $E$. huxleyi are frequently at $4 \mu \mathrm{mol} \mathrm{\textrm {L } ^ { - 1 }}$ or higher, concentrations of ortho-phosphate are often lower than $0.2 \mu \mathrm{mol} \mathrm{L}{ }^{-1}$ (Veldhuis et al. 1994; Fernandez et al. 1994; Van der Wal et al. 1995). Coccolithophore dynamics off Bermuda support this pattern, indicating increasing coccolithophore abundances to coincide with the seasonal advection of nitrate-rich but phosphate-poor waters to the euphotic zone (Haidar and Thierstein 2001). Coccolithophores may thrive best under such conditions due to their high affinity for nutrients, in particular for phosphate. In environments with fluctuating nutrient and/or energy supply diatoms are likely to dominate due to their higher capacity for luxury consumption compared to coccolithophores (Iglesias-Rodríguez et al. 2002; Falkowski et al. this volume).

Aside from physiological constraints regarding light and nutrient utilisation, grazer control equally influences the seasonal succession of the major phytoplankton groups. While the frustules of diatoms appear to serve as an effective mechanical protection against various types of microzooplankton predators (Hamm et al. 2003), the coccosphere of coccolithophores does not seem to provide the same degree of protection (Sikes and Wilbur 1982; Harris 1994). Due to its high intrinsic growth rate, microzooplankton has the potential to propagate at al- 
most the same rate as its prey and thereby impede phytoplankton mass development. Grazing of copepods on microzooplankton can, in turn, considerably reduce the grazing pressure in this size class (cascade effect) and stimulate the microbial foodweb. Cascade effects of copepods on microzooplankton were in fact found to promote blooms of E. huxleyi (Nejstgaard et al. 1997). Due to the comparatively slow development of copepods and other carnivorous predators, mesozooplankton control typically occurs later in the seasonal cycle. This may be one of the reasons for the timing of E. huxleyi blooms, which are often confined to the late spring/summer period.

In summary, observed differences in photosynthesis versus irradiance relationships, nutrient uptake kinetics and food web interactions between E. huxleyi and other bloom-forming phytoplankton groups are - to a certain extent - in agreement with observed mass occurrences of E. huxleyi. For instance, E. huxleyi blooms coincide with relatively high nitrate and low phosphate levels and typically occur in stratified waters with high mixed layer irradiances. This is consistent with the observed tolerance of E. huxleyi to high light intensities, the low affinity for nitrate and high affinity for phosphate and organic phosphorus as well as a low capacity for luxury consumption. The relatively small cell size, which makes it more prone to microzooplankton grazing as compared to most diatoms, may repress mass developments of E. huxleyi at times and in areas where microzooplankton development is not kept in check by higher trophic levels. Despite the breadth of information recently becoming available on one of the best-studied marine phytoplankton species, our understanding of the complex interplay determining phytoplankton distribution and succession in the sea, however, is still insufficient to fully explain and forecast the geographical distribution and seasonal timing of $E$. huxleyi blooms.

\section{Future scenarios}

For about the last 20 million years atmospheric $\mathrm{pCO}_{2}$ has remained $\leq 300 \mathrm{ppm}$ (Berner 1990), fluctuating between $180 \mathrm{ppmv}$ in glacial and $280 \mathrm{ppmv}$ in interglacial times (Petit et al. 1999). With the beginning of the industrial revolution, burning of fossil fuel and changes in land use have disturbed this apparent balance. At present the $\mathrm{pCO}_{2}$ has reached about $370 \mathrm{ppmv}$ and is expected to rise to $750 \mathrm{ppmv}$ by the end of this century (assuming IPCC's 'business as usual' scenario IS 92a). Since the atmosphere and ocean surface layer constantly exchange $\mathrm{CO}_{2}$, changes in atmospheric $\mathrm{pCO}_{2}$ will invariably affect the surface ocean carbonate system. While increasing $\mathrm{CO}_{2}$ causes the $\mathrm{pH}$ and $\mathrm{CO}_{3}{ }^{2-}$ concentration to decrease, the large pool of $\mathrm{HCO}_{3}{ }^{-}$remains more or less constant. The expected increase in atmospheric $\mathrm{pCO}_{2}$ is estimated to triple surface water $\mathrm{CO}_{2}$ concentrations relative to pre-industrial values by the end of this century. Concomitantly, seawater $\mathrm{pH}$ and $\mathrm{CO}_{3}{ }^{2-}$ concentrations will have dropped by 0.4 units and $50 \%$, respectively (Fig. 2). 
As a potent greenhouse gas, $\mathrm{CO}_{2}$ has also been held responsible for the observed rise in average global temperatures. Global warming increases thermal stratification of the surface ocean, while enhanced freshwater input from melting ice lowers surface layer salinity. Both of these effects further increase density stratification of the upper ocean. Enhanced upper ocean stratification has two effects on phytoplankton: it reduces nutrient supply from deeper layers and increases light availability due to shoaling of the upper mixed layer (Fig. 3). How will these changes in marine environmental conditions affect coccolithophore growth and calcification and to what extent will it influence the distribution and productivity of E. huxleyi relative to other dominant phytoplankton groups (Fig. 8)? What will be the potential consequences for marine ecosystem regulation and ultimately, how does this affect the biological carbon pumps?

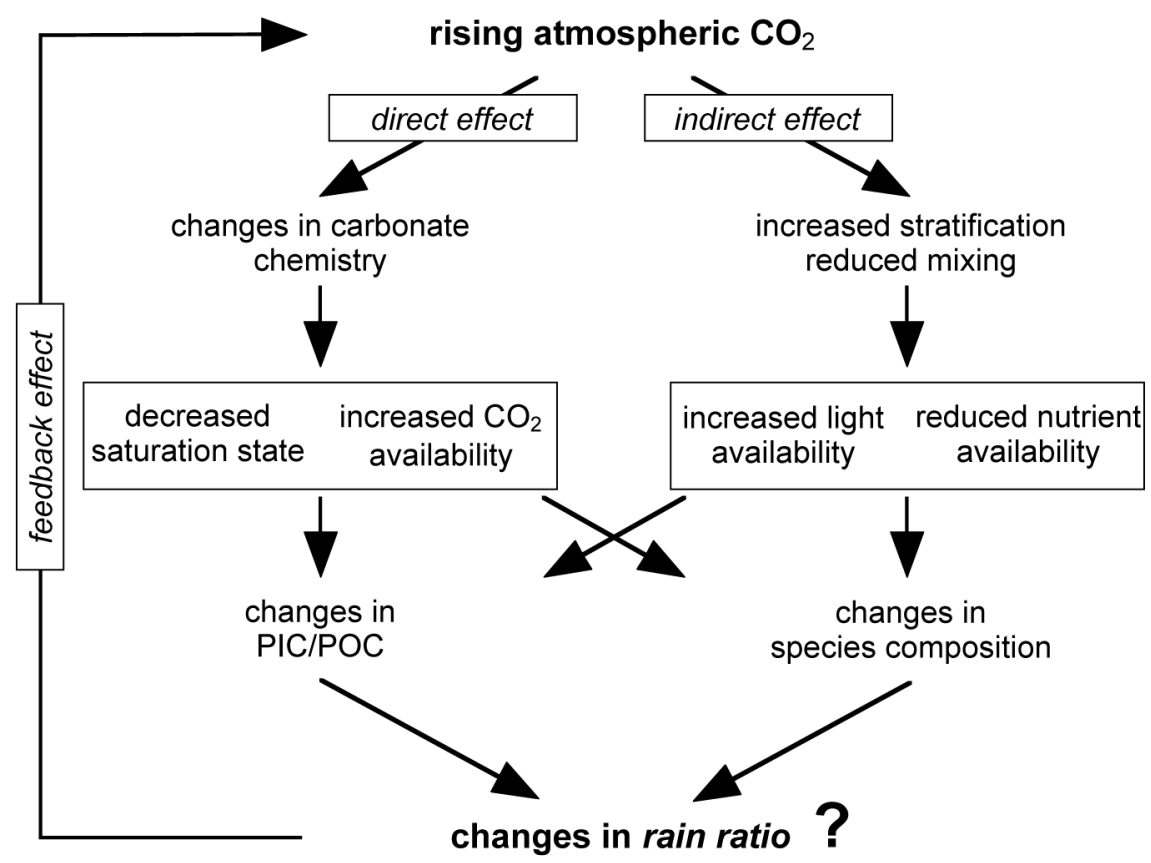

Fig. 8. Effects of rising atmospheric $\mathrm{CO}_{2}$ on the surface ocean and its likely impact on phytoplankton: Increasing $\mathrm{CO}_{2}$ levels directly cause changes in surface ocean carbonate chemistry, such as elevated $\mathrm{CO}_{2}$ concentrations or decreased $\mathrm{CaCO}_{3}$ saturation state. Indirect effects are those associated with enhanced stratification, such as increased light or reduced nutrient availability. These $\mathrm{CO}_{2}$ related changes in the growth conditions are likely to affect the ecophysiology of coccolithophores and structure of phytoplankton communities, with possible consequences for the rain ratio. 
Table 1. Predicted changes in abiotic factors (Houghton et al. 2001) and potential responses in photosynthesis, calcification, PIC/POC of coccolithophores as well as potential shift in the dominance between coccolithophores and diatoms (+, - and _ denote an increase, decrease and no likely change, respectively). Changes in abiotic factors refer to the means of the upper mixed layer (UML). Potential responses in the physiology of coccolithophores were assessed on the basis of the expected changes in the UML and the sensitivity of respective processes. Potential changes in the dominance between coccolithophores and diatoms were assessed on the basis of the ecological niche of these two functional groups.

\begin{tabular}{lccccc}
\hline $\begin{array}{l}\text { Changes } \\
\text { in abiotic factors }\end{array}$ & Photosynth. & $\begin{array}{c}\text { Physiology } \\
\text { Calcific. }\end{array}$ & PIC/POC & $\begin{array}{c}\text { Ecology } \\
\text { Cocco./Diatoms }\end{array}$ & $\begin{array}{c}\text { Biogeochem. } \\
\text { Rain Ratio }\end{array}$ \\
\hline $\begin{array}{l}\text { increasing } \mathrm{CO}_{2} / \\
\text { decreasing pH }\end{array}$ & $+{ }^{1-7}$ & $-{ }^{5} /-4,7$ & $-{ }^{4,5,7}$ & $+6 /-4$ & $+/-?$ \\
$\begin{array}{l}\text { increasing mean ir- } \\
\text { radiance }\end{array}$ & $+{ }^{5,8-11}$ & $+{ }^{1,5,12-14}$ & $+{ }^{5,13,14 /-}$ & $+{ }^{11,16}$ & $+?$ \\
$\begin{array}{l}\text { decreasing nutrient } \\
\text { availability }\end{array}$ & $-7,17-19$ & $++^{7,17-19}$ & $++^{7,17-19} /{ }_{-}^{19}$ & $+{ }^{19-21}$ & $+?$ \\
\hline
\end{tabular}

${ }^{1}$ Paasche 1964; ${ }^{2}$ Nimer and Merrett 1993; ${ }^{3}$ Nielsen 1995; ${ }^{4}$ Riebesell et al. 2000; ${ }^{5}$ Zondervan et al. 2002; ${ }^{6}$ Rost et al. 2003; ${ }^{7}$ Berry et al. 2002; ${ }^{8}$ Paasche $1967 ;{ }^{9}$ Van Bleijswijk et al. 1994; ${ }^{10}$ Nielsen 1997; ${ }^{11}$ Nanninga and Tyrrell 1996; ${ }^{12}$ Van der Wal et al. $1995 ;{ }^{13}$ Balch et al. 1996; ${ }^{14}$ Paasche 1999; ${ }^{15}$ Balch et al. 1992; ${ }^{16}$ Tyrrell and Taylor $1996 ;{ }^{17}$ Paasche and Brubak 1994;

${ }^{18}$ Paasche 1998; ${ }^{19}$ Riegman et al. 2000; ${ }^{20}$ Riegman et al. 1992; ${ }^{21}$ Egge and Aksnes 1992

In view of the inherent complexity of biological systems, including marine pelagic systems, it would be premature to attempt a forecast of marine phytoplankton responses to global change. In the following, we will outline possible, yet hypothetical scenarios for the effect of environmental change on coccolithophores (results of our assessment are summarized in Table. 1).

In principle, coccolithophores may benefit from the present increase in atmospheric $\mathrm{pCO}_{2}$ and related changes in seawater carbonate chemistry. At preindustrial $\mathrm{CO}_{2}$ levels, rates of photosynthetic carbon fixation of E. huxleyi and Gephyrocapsa oceanica are well below $\mathrm{CO}_{2}$ saturation. In comparison, photosynthesis of other bloom-forming phytoplankton groups such as diatoms and Phaeocystis are less $\mathrm{CO}_{2}$-sensitive due to their efficient CCMs (Rost et al. 2003). Although under natural conditions $\mathrm{CO}_{2}$ limitation is likely to be of minor importance for the proliferation of $E$. huxleyi compared to other limiting resources and loss processes, increasing $\mathrm{CO}_{2}$ availability may improve the overall resource utilisation of E. huxleyi and possibly of other fast-growing coccolithophore species. If this provides an ecological advantage for coccolithophores, rising atmospheric $\mathrm{CO}_{2}$ could potentially increase the contribution of calcifying phytoplankton to overall primary production.

On the cellular level the ratio of calcium carbonate to organic carbon production is expected to change as calcification and photosynthesis respond in different ways to $\mathrm{CO}_{2}$-related changes in carbonate chemistry. Whereas the observed 
stimulation of photosynthesis due to increased $\mathrm{CO}_{2}$ availability increases the organic carbon quota of the cell, calcification remains constant or decreases in response to a decline in the calcium carbonate saturation state, depending on light conditions. As a consequence, the cellular PIC/POC ratio decreases with increasing $\mathrm{CO}_{2}$. This effect has been observed under various irradiances and nutrient concentrations in lab experiments with mono-specific cultures (Riebesell et al. 2000a; Zondervan et al. 2002; Berry et al. 2002), as well as in E. huxleyi-dominated natural phytoplankton assemblages in a mesocosm study (Zondervan pers. com.). Whether this affects the ecological competitiveness of calcifying phytoplankton and to what extent it influences losses due to grazing, viral infection or autolysis, is presently unknown.

Whatever the purpose of calcification in coccolithophores, continued acidification of surface seawater due to rising atmospheric $\mathrm{CO}_{2}$ will further deteriorate the chemical conditions for biogenic calcification. An overall decline in pelagic calcification is expected to decrease the ratio of calcium carbonate to organic carbon in the vertical flux of biogenic material (rain ratio), with corresponding effects on air/sea $\mathrm{CO}_{2}$ exchange (see above). The overall effect will be an increase in the $\mathrm{CO}_{2}$ storage capacity of the upper ocean, constituting a negative feedback to rising atmospheric $\mathrm{CO}_{2}$ (Zondervan et al. 2001).

Changes in surface ocean stratification are likely to affect overall primary production as well as phytoplankton species composition. Enhanced stratification and the concomitant decrease in nutrient supply is likely to cause an overall decline in oceanic primary production as well as a poleward shift due to a longer growing season at high latitudes. Recent model calculations indicate large regional differences in the effects of climate change on the marine ecosystem, predicting a $20 \%$ decrease in export production in low latitudes and a $30 \%$ increase in high latitudes for a $2 \times \mathrm{CO}_{2}$ scenario (Bopp et al. 2001). For coccolithophores the projected increase in stratification may prove advantageous since their blooms predominantly occur in well-stratified waters, often in subpolar latitudes. An increase in coccolithophore-dominated regions at the expense of diatom-dominated new-production systems would increase the global rain ratio. As high irradiances and low nutrient levels, but particularly the combination of both, have been shown to stimulate calcification relative to photosynthesis, enhanced stratification may also increase the $\mathrm{PIC} / \mathrm{POC}$ ratio on the cellular level. This in turn may partly compensate for the reverse effect by $\mathrm{CO}_{2}$-related changes in carbonate chemistry.

As illustrated above, a climate-induced increase in the contribution of coccolithophores to total primary production and a $\mathrm{CO}_{2}$-related decrease in the cellular ratio of PIC/POC production, both of which are hypothetical at present, would have opposing effects on the marine carbon cycle. The net effect on carbon cycling ultimately depends on the relative importance and sensitivity of each of these processes to global change. In addition, possible changes at the level of primary producers, such as those outlined above, are likely to be amplified, compensated or reversed by interference from higher trophic levels, which themselves are bound to respond to environmental change. Understanding the complex structure and regulation of marine pelagic ecosystems, their responses to global environ- 
mental change and the consequences thereof for marine biogeochemical cycling will be a major challenge for marine sciences in the coming decades.

\section{Acknowledgements}

We would like to thank David Archer, Michael Steinke, and Toby Tyrrell for their constructive comments on the manuscript.

\section{References}

Anning T, Nimer N, Merret MJ, Brownlee C (1996) Costs and benefits of calcification in coccolithophorids. J Marine Sys 9: 45-56

Antia AN, Koeve W, Fischer G, Blanz T, Schulz-Bull D, Scholten J, Neuer S, Kremling K, Kuss J, Peinert R, Hebbeln D, Bathmann U, Conte M, Fehner U, Zeitzschel B (2001) Basin-wide particulate carbon flux in the Atlantic Ocean: regional export patterns and potential for atmospheric $\mathrm{CO}_{2}$ sequestration. Global Biogeochem Cy 15 (4): 845-862

Archer D, Maier-Reimer E (1994) The effect of deep-sea sedimentary calcite preservation on atmospheric $\mathrm{CO}_{2}$ concentrations. Nature 367: 260-263

Armstrong RA, Lee C, Hedges JI, Honjo S, Wakeham SG (2002) A new, mechanistic model for organic carbon fluxes in the ocean: Based on the quantitative association of POC with ballast minerals. Deep-Sea Res 49 (2): 219-236

Badger MR, Palmqvist K, Yu J-W (1994) Measurement of $\mathrm{CO}_{2}$ and $\mathrm{HCO}_{3}{ }^{-}$fluxes in cyanobacteria and microalgae during steady-state photosynthesis. Physiol Plantarum 90: $529-536$

Badger MR, Andrews TJ, Whitney SM, Ludwig M, Yellowlees DC, Leggat W, Price GD (1998) The diversity and coevolution of Rubisco, plastids, pyrenoids, and chloroplastbased $\mathrm{CO}_{2}$-concentrating mechanisms in algae. Can J Bot 76: 1052-1071

Balch WM, Holligan PM, Ackleson SG, Voss KJ (1991) Biological and optical properties of mesoscale coccolithophore blooms in the Gulf of Maine. Limnol Oceanogr 36 (4): $629-643$

Balch WM, Holligan PM, Kilpatrick KA (1992) Calcification, photosynthesis and growth of the bloom-forming coccolithophore, Emiliania huxleyi. Cont Shelf Res 12 (12): $1353-1374$

Balch WM, Fritz J, Fernandez E (1996) Decoupling of calcification and photosynthesis in the coccolithophore Emiliania huxleyi under steady-state light-limited growth. Marine Ecol-Prog Ser 142: 87-97

Berner RA (1990) Atmospheric carbon dioxide levels over phanerozoic time. Science 249: 1382-1386

Berry L, Taylor AR, Lucken U, Ryan KP, Brownlee C (2002) Calcification and inorganic carbon acquisition in coccolithophores. Aust J Plant Physiol 29: 289-299

Bopp L, Monfray P, Aumont O, Dufresne J-L, Le Treut H, Madec G, Terray L, Orr JC (2001) Potential impact of climate change on marine export production. Global Biogeochem Cy 15: 81-99 
Boyd PW, Doney SC (2002) Modelling regional responses by marine pelagic ecosystems to global change. Geophys Res Lett 29 (16): 10.1029/2001GL014130

Brand LE (1991) Minimum iron requirements of marine phytoplankton and the implications for the biogeochemical control of reproduction. Limnol Oceanogr 36: 1756-1771

Brownlee C, Nimer N, Dong LF, Merrett MJ (1994) Cellular regulation during calcification in Emiliania huxleyi. In: Green JC, Leadbeater BSC (eds) The haptophyte algae. Clarendon Press, Oxford, pp 133-148

Buitenhuis E, Van Bleijswijk J, Bakker D, Veldhuis M (1996) Trends in inorganic and organic carbon in a bloom of Emiliania huxleyi (Prymnesiophyceae) in the North Sea. Marine Ecol-Prog Ser 143: 271-282

Buitenhuis ET, Baar HJW, Veldhuis MJW (1999) Photosynthesis and calcification by Emiliania huxleyi (Prymnesiophyceae) as a function of inorganic carbon species. J Phycol 35 (5): 949-959

Burkhardt S, Amoroso G, Riebesell U, Sültemeyer D (2001) $\mathrm{CO}_{2}$ and $\mathrm{HCO}_{3}{ }^{-}$uptake in marine diatoms acclimated to different $\mathrm{CO}_{2}$ concentrations. Limnol Oceanogr 46 (6): $1378-1391$

Clark DR, Flynn KJ (2000) The relationship between the dissolved inorganic carbon concentration and growth rate in marine phytoplankton. P Roy Soc Lond B 267: 953-959

Egge JK, Aksnes DL (1992) Silicate as regulating nutrient in phytoplankton competition. Marine Ecol-Prog Ser 83: 281-289

Fernandez E, Balch WM, Maranon E, Holligan PM (1994) High rates of lipid biosynthesis in cultured, mesocosm and coastal populations of the coccolithophore Emiliania huxleyi. Marine Ecol-Prog Ser 114: 13-22

Frankignoulle M, Canon C, Gattuso J-P (1994) Marine calcification as a source of carbon dioxide: Positive feedback of increasing atmospheric $\mathrm{CO}_{2}$. Limnol Oceanogr 39 (2): 458-462

Gattuso J-P, Frankignoulle M, Bourge I, Romaine S, Buddemeier RW (1998) Effect of calcium carbonate saturation of seawater on coral calcification. Global Planet Change 18: $37-46$.

Geider JG, MacIntyre HL (2001) Physiology and biochemistry of photosynthesis and algal carbon acquisition. In: Williams PJleB, Thomas DN, Reynolds CS (eds) Phytoplankton Productivity - Carbon Assimilation in Marine and Freshwater Ecosystems. Blackwell Science, pp 44-77

Grime JP (1979) Plant Strategies and Vegetation Processes. John Wiley, New York

Hamm CE, Merkel R, Springer O, Jurkojc P, Maier C, Prechtel K, Smetacek V (2003) Architecture and material properties of diatom shells provide effective mechanical protection, Nature 421: 841-843

Haidar AT, Thierstein HR (2001) Coccolithophore dynamics off Bermuda (N. Atlantic). Deep-Sea Res II 40: 1925-1956

Harris RP (1994) Zooplankton grazing on the coccolithophore Emiliania huxleyi and its role in inorganic carbon flux. Mar Biol 119: 431-439

Harrison KG (2000) Role of increased marine silica input on paleo-pCO2 levels. Paleoeanography 15 (3): 292-298

Henrich R (1989) Diagenetic environments of authigenic carbonates and opal-ct crystallization in Lower Miocene to Upper Oligocene Deposits of the Norwegian Sea (ODP Site 643, Leg 104). In: Eldholm O, Thiede J, Taylor E (eds) Proceedings of the Ocean Drilling Program, Scientific Results, 104: 233-248 
Holligan PM, Fernandez E, Aiken J, Balch WM, Boyd P, Burkill PH, Finch M, Groom SB, Malin G, Muller K, Purdie DA, Robinson C, Trees CC, Turner SM, Van der Wal P (1993) A biogeochemical study of the coccolithophore Emiliania huxleyi, in the North Atlantic. Global Biogeochem Cy 7: 879-900

Horita J, Zimmermann H, Holland HD (2002) Chemical evolution of seawater during the Phanerozoic: Implications from the record of marine evaporates. Geochim Cosmochim Ac 66 (21): 3733-3756

Houghton JT, Meira Filho LG, Callander BA, Harris N, Kattenberg A, Maskell K (1995) Climate Change 1995: The Science of Climate Change. Contribution of Working Group I to the Second Assessment Report of the Intergovernmental Panel of Climate Change, Cambridge Univ. Press, Cambridge, UK and New York, USA

Houghton JT, Ding Y, Griggs DJ, Noguer M, Van der Linden PJ, Dai X, Maskell K, Johnson CA (2001) Climate Change 2001: The Scientific Basis: Contribution of Working Group I to the Third Assessment Report of the Intergovernmental Panel of Climate Change, Cambridge Univ. Press, Cambridge, UK and New York, USA

Ietswaart T, Schneider PJ, Prins RA (1994) Utilisation of organic nitrogen sources by two phytoplankton species and a bacterial isolate in pure and mixed culture. Appl Environ Microb 60: 1554-1560

Iglesias-Rodríguez MD, Brown CW, Scott CD, Kleypas J, Kolber D, Kolber Z, Hayes PK, Falkowski PG (2002) Representing key phytoplankton functional groups in ocean carbon cycle models: Coccolithophorids. Global Biogeochem Cy 16 (4): 10.1029/2001GB001454

Klaas C, Archer DE (2002) Association of sinking organic matter with various types of mineral ballast in the deep sea: Implications for the rain ratio. Global Biogeochem Cy 16 (4) 1116, doi:10.1029/2001GB001765

Linschooten C, Van Bleijswijk JDL, Van Emburg PR, De Vrind JPM, Kempers ES, Westbroek P, de Vrind-de Jong EW (1991) Role of the light-dark cycle and medium composition on the production of coccoliths by Emiliania huxleyi (Haptophyceae). J Phycol 27: 82-86

Lovelock JE (1979) Gaia. A new look at life on earth. Oxford University Press, Oxford

McIntyre A, Ruddiman WF, Jantzen R (1972) Southward penetration of the North Atlantic Polar Front: faunal and floral evidence of large-scale surface water mass movements over the last 225,000 years. Deep-Sea Res 19: 61-77

Morel FMM, Reinfelder JR, Roberts SB, Chamberlain CP, Lee JG, Yee D (1994) Zinc and carbon co-limitation of marine phytoplankton. Nature 369: 740-742

Morse JW, Mackenzie FT (1990) Geochemistry of Sedimentary Carbonates. Elsevier, Amsterdam

Muggli DL, Harrison PJ (1996) Effects of nitrogen source on the physiology and metal nutrition of Emiliania huxleyi grown under different iron and light conditions. Marine Ecol-Prog Ser 130: 255-267

Nanninga HJ, Tyrrell T (1996) Importance of light for the formation of algal blooms by Emiliania huxleyi. Marine Ecol-Prog Ser 136: 195-203

Nejstgaard JC, Gismervik I, Solberg PT (1997) Feeding and Reproduction by Calanus finmarchicus, and microzooplankton grazing during mesocosm blooms of diatoms and the coccolithophore Emiliania huxleyi. Marine Ecol-Prog Ser 147: 197-217

Nielsen MV (1995) Photosynthetic characteristics of the coccolithophorid Emiliania huxleyi (Prymnesiophyceae) exposed to elevated concentrations of dissolved inorganic carbon. J Phycol 31: 715-719 
Nielsen MV (1997) Growth, dark respiration and photosynthetic parameters of the coccolithophorid Emiliania huxleyi (Prymnesiophyceae) acclimated to different daylengthsirradiance combinations. J Phycol 33: 818-822

Nimer NA, Merret MJ (1993) Calcification rate in Emiliania huxleyi Lohmann in response to light, nitrate and availability of inorganic carbon. New Phytol 123: 673-677

Nimer NA, Merret MJ (1996) The development of a $\mathrm{CO}_{2}$-concentrating mechanism in Emiliania huxleyi. New Phytol 133: 383-389

Paasche E (1962) Coccolith formation. Nature 193: 1094-1095

Paasche E (1964) A tracer study of the inorganic carbon uptake during coccolith formation and photosynthesis in the coccolithophorid Coccolithus huxleyi. Physiol Plantarum Supplement 3: 1-82

Paasche E (1965) The effect of 3-(p-chlorophenyl)-1,1-dimethylurea (CMU) on photosynthesis and light-dependent coccolith formation in Coccolithus huxleyi. Physiol Plantarum 18: 138-145

Paasche E (1966) Adjustment to light and dark rates of coccolith formation. Physiol Plantarum 19: 271-278

Paasche E (1967) Marine plankton algae grown with light-dark cycles. I. Coccolithus huxleyi. Physiol Plantarum 20: 946-956

Paasche E (1969) Light-dependent coccolith formation in the two forms of Coccolithus pelagicus. Arch Mikrobiol 67: 199-208

Paasche E (1998) Roles of nitrogen and phosphorus in coccolith formation in Emiliania huxleyi (Prymnesiophyceae). Eur J Phycol 33: 33-42

Paasche E (1999) Reduced coccolith calcite production under light-limited growth: a comparative study of three clones of Emiliania huxleyi (Prymnesiophyceae). Phycologia 38: $508-516$

Paasche E (2002) A review of the coccolithophorid Emiliania huxleyi (Prymnesiophyceae), with particular reference to growth, coccolith formation, and calcificationphotosynthesis interactions. Phycologia 40 (6): 503-529

Paasche E, Brubak S (1994) Enhanced calcification in the coccolithophorid Emiliania huxleyi (Haptophyceae) under phosphorus limitation. Phycologia 33: 324-330

Paasche E, Brubak S, Skattebøl S, Young JR, Green JC (1996) Growth and calcification in the coccolithophorid Emiliania huxleyi (Haptophyceae) at low salinities. Phycologia 35: 394-403

Page S, Hipkin CR, Flynn KJ (1999) Interactions between nitrate and ammonium in Emiliania huxleyi. J Exp Mar Biol Ecol 236: 307-319

Palenik B, Henson SE (1997) The use of amides and other organic nitrogen sources by the phytoplankton Emiliania huxleyi. Limnol Oceanogr 42: 1544-1551

Petit JR, Jouzel J, Raynaud D, Barkov NI, Barnola J-M, Basile I, Bender M, Chappellaz J, Davis M, Delaygue G, Delmotte M, Kotlyakov VM, Legrand M, Lipenkov VY, Lorius C, Pepin L, Ritz C, Saltzman E, Stievenard M (1999) Climate and atmospheric history of the past 420,000 years from the Vostok ice core, Antarctica. Nature 399: 429-436

Purdie DA, Finch MS (1994) Impact of coccolithophorids on dissolved carbon dioxide in sea water enclosures in a Norwegian Fjord. Sarsia 79: 379-387

Raven JA (1997) The vacuole: A cost-benefit analysis. Adv Bot Res 25: 59-86

Raven JA, Johnston AM (1991) Mechanisms of inorganic-carbon acquisition in marine phytoplankton and their implications for the use of other resources. Limnol Oceanogr 36 (8): 1701-1714 
Richardson K, Beardall J, Raven JA (1983) Adaptation of unicellular algae to irradiance: an analysis of strategies. New Phytol 93: 157-191

Ridgwell AJ, Watson AJ, Archer DE (2002) Modelling the response of the oceanic Si inventory to perturbation, and consequences for atmospheric $\mathrm{CO}_{2}$. Global Biogeochem Cy 16 (4) 1071, doi:10.1029/2002GB001877

Riebesell U, Zondervan I, Rost B, Tortell PD, Zeebe RE, Morel FMM (2000a) Reduced calcification in marine plankton in response to increased atmospheric $\mathrm{CO}_{2}$. Nature 407: 634-637

Riebesell U, Revill AT, Holdsworth DG, Volkman JK (2000b) The effects of varying $\mathrm{CO}_{2}$ concentration on lipid composition and carbon isotope fractionation in Emiliania huxleyi. Geochim Cosmochim Ac 64 (24): 4179-4192

Riegman R, Noordeloos AAM, Cadée GC (1992) Phaeocystis blooms and eutrophication of the continental coastal zones of the North Sea. Mar Biol 112: 479-484

Riegman R, Stolte W, Noordeloos AAM, Slezak D (2000) Nutrient uptake and alkaline phosphatase (EC3:1:3:1) activity of Emiliania huxleyi (Prymnesiophyceae) during growth under $\mathrm{N}$ and $\mathrm{P}$ limitation in continuous cultures. J Phycol 36: 87-96

Robertson JE, Robinson C, Turner DR, Holligan P, Watson AJ, Boyd P, Fernandez E, Finch M (1994) The impact of a coccolithophore bloom on oceanic carbon uptake in the northeast Atlantic during summer 1991. Deep-Sea Res 41 (2): 297-314

Rost B, Zondervan I, Riebesell U (2002) Light-dependent carbon isotope fractionation in the coccolithophorid Emiliania huxleyi. Limnol Oceanogr 47 (1): 120-128

Rost B, Riebesell U, Burkhardt S, Sültemeyer D (2003) Carbon acquisition of bloomforming marine phytoplankton. Limnol Oceanogr 48 (1): 55-67

Sikes CS, Roer RD, Wilbur KM (1980) Photosynthesis and coccolith formation: Inorganic carbon sources and net inorganic reaction of deposition. Limnol Oceanogr 25 (2): $248-261$

Sikes CS, Wilbur KM (1982) Function of coccolith formation. Limnol Oceanogr 27 (1): $18-26$

Sikes CS, Wheeler AP (1982) Carbonic anhydrase and carbon fixation in coccolithophorids. J Phycol 18: 423-426

Sunda WG, Huntsmann SA (1995) Cobalt and zinc interreplacement in marine phytoplankton: biological and geochemical implications. Limnol Oceanogr 40: 1404-1417

Thierstein HR, Geitzenauer KR, Molfino B, Shackleton NJ (1977) Global synchroneity of late Quaternary coccolith datum levels: validation by oxygen isotopes. Geology 5: 400-404

Tortell PD, Giocoma RD, Sigman DM, Morel FMM (2002) $\mathrm{CO}_{2}$ effects on taxonomic composition and nutrient utilization in an Equatorial Pacific phytoplankton assemblage. Marine Ecol-Prog Ser 236: 37-43

Tyrrell T, Taylor AH (1996) A modelling study of Emiliania huxleyi in the NE Atlantic. J Marine Sys 9: 83-112

Van Bleijswijk JDL, Kempers RS, Veldhuis MJ, Westbroek P (1994). Cell and growth characteristics of types A and B of Emiliania huxleyi (Prymnesiophyceae) as determined by flow cytometry and chemical analyses. J Phycol 30: 230-241

Van der Wal P, Kempers RS, Veldhuis MJW (1995) Production and downward flux of organic matter and calcite in a North Sea bloom of the coccolithophore Emiliania huxleyi. Marine Ecol-Prog Ser 126: 247-265 
Veldhuis MJW, Stoll M, Bakker D, Brummer G-J, Kraak M, Kop A, Van Weerlee E, Van Koutrik A, Riddervold Heimdal B (1994) Calcifying phytoplankton in Bjornafjorden, Norway. The prebloom situation. Sarsia 79: 389-399

Volk T (1989) Sensitivity of climate and atmospheric $\mathrm{CO}_{2}$ to deep-ocean and shallowocean carbonate burial. Nature 337: 637-640

Wolf-Gladrow DA, Riebesell U, Burkhardt S, Bijma J (1999) Direct effects of $\mathrm{CO}_{2}$ concentration on growth and isotopic composition of marine plankton, Tellus 51 (2): $461-476$

Young JR (1994) Function of coccoliths. In: Winter A, Siesser WG (eds) Coccolithophores. Cambridge University Press, Cambridge, pp 63-82

Zeebe RE, Wolf-Gladrow DA (2001) $\mathrm{CO}_{2}$ in Seawater: Equilibrium, Kinetics, Isotopes. Elsevier Oceanography Book Series 65, Amsterdam

Ziveri P, Broerse ATC, Hinte JE, Van Westbroek P, Honjo S (2000) The fate of coccoliths at $48^{\circ} \mathrm{N} 21^{\circ} \mathrm{W}$, northeastern Atlantic. Deep-Sea Res II 47: 1853-1875

Zondervan I, Zeebe RE, Rost B, Riebesell U (2001) Decreasing marine biogenic calcification: A negative feedback on rising atmospheric $\mathrm{pCO}_{2}$. Global Biogeochem Cy 15 (2): 507-516

Zondervan I, Rost B, Riebesell U (2002) Effect of $\mathrm{CO}_{2}$ concentration on the PIC/POC ratio in the coccolithophore Emiliania huxleyi grown under light-limiting conditions and different daylengths. J Exp Mar Biol Ecol 272: 55-70 